fertilisers in England and Germany, but as the economic conditions in the two countries were, and still are, wholly abnormal and scarcely comparable, it is not easy to determine their actual significance or to forecast their eventual importance.

In conclusion, reference is made to the attempts to develop nitrogen fixation in this country by Messrs. Brunner, Mond, and Co., who have taken over the projected Government factory at Billingham, and by Cumberland Coal Power and Chemicals, Ltd., who are to work the Claude process of synthetic ammonia.

The entire Report constitutes one of the most valuable lessons of the war, and deserves the most serious study. The subject of nitrogen fixation has not yet received the attention in this country which its great importance merits.

\title{
Obituary.
}

\section{Emile Boutroux.}

$\mathrm{T}^{\mathrm{H}}$ $E$ death of Emile Boutroux at the age of seventy-six is the loss not only of one who has been for a generation a central figure in the circle of French philosophy, known everywhere in Europe and America, but also of one who by the charm of his personality seemed to embody all that is most attractive in the French genius. It will necessarily cast a gloom on the meeting of the Société Française de Philosophie which is to be held in Paris between Christmas and the New Year and to which English, American, and Italian philosophical societies are sending delegates, for he was to have been its président d'honneur. To those who have known him at former international philosophical congresses his loss will mean much more than his vacant chair.

The last years of Boutroux's life had been saddened by the loss of friends. He felt deeply the death of his brother-in-law, Henri Poincaré, in I9r 3 at the age of fifty-eight, cut off, as it seemed, in his full intellectual strength. In a conversation with the present writer a few years ago he remarked that his one dearest wish was to be able to show the fruitfulness of Poincaré's ideas in philosophy. In I9I9 he lost his wife, who had been for many years his inseparable companion at home and in all his lecture tours in foreign countries. Yet with all the weight of sorrow and the increasing infirmities of old age (he suffered much from deafness and eye trouble) he retained to the end his extraordinary vivacity and charm of conversation and his power of sympathetic control when addressing a meeting.

Emile Boutroux represents a distinct and very important position in the history of contemporary philosophy, especially in relation to the modern scientific revolution. From his student days he devoted his attention to that conception of a universal determinism which, from the time of Descartes down to the great scientific development in the nineteenth century, had seemed to be the absolute and necessary basis of physical science. In 1874 he presented a thesis to the Sorbonne for his doctorate. It was entitled "De la Contingence des Lois de la Nature." For twenty years this book attracted little attention outside the circle of his students and philosophical colleagues. He was fully engaged in lecturing and teaching, and some of his lecture courses NO. 27 I 8 , VOL. IO8] were published as studies in the history of philosophy. In 1895, however, at the urgent request of his friends, he republished his thesis in its original form, and since then it has gone through innumerable editions and has been translated into all the principal languages.

The main idea of the thesis Boutroux probably owed to his older contemporary, Lachelier, but the work itself is of striking originality. The argument is that nowhere, not even in the logical syllogism, do we get the type of necessity which is represented by the proposition of identity, $A$ is $A$, and yet this and nothing short of this will satisfy the ideal of universal science. He went on to prove that the more we advance from the abstract to the concrete, from mathematics to physics, from physics to biology, from biology to psychology, the more we see the range of necessity being restricted and that of contingency growing larger. The suggestiveness of his theory rather than the systematic expression which he was able to give to it marks its importance. It places him in the direct line of that philosophical speculation which, starting with Maine de Biran in the beginning of the nineteenth century, may be traced through Ravaisson, Lachelier, and Boutroux himself to the present philosophers, Bergson, Le Roy, Blondel, and Laberthonière, all of whom were at one time his pupils.

H. W. C.

\section{Prof. Peter Thompson.}

Prof. Peter Thompson, whose untimely and deeply lamented death occurred at Penmaenmawr on November 16 , early showed an unusual aptitude for human anatomy. He obtained a special mark of distinction in the subject when a student, and it gained him the gold medal on taking the M.D. (Victoria) from Owen's College, Manchester. He soon won a reputation as a brilliant and enthusiastic teacher after he was appointed senior demonstrator of anatomy, at Owen's College. This reputation he fully maintained when he came to London, first as lecturer at the Middlesex Hospital, and later as professor of anatomy at King's College. In 1912 he was elected professor of anatomy and dean of the medical faculty of the University of Birmingham.

Prof. Thompson's contributions to the literature 